MULTI-MODES MEASURES: FROM POTHOLES TO POLICE

by

Elinor Ostrom

Workshop in Political Theory and Policy Analysis
Indiana University

Paper presented at a conference on "Product

Challenges for the Public Service" organiztivity and Program Evaluation: mental Training Comnittee on June 6,1975 .

Research on multi-mode approaches to the measurement of the output of National Needs Division of the National by the Research Applied to of Grant Number GI 38535. 


\title{
MULTI-MODE MEASURES: FROM POTHOLES TO POLICE
}

by

Elinor Ostrom

\begin{abstract}
On Palm Sunday one year ago, I found myself walking down an Indianapolis street, carrying a yardstick and dashing out between passing cars to measure the potholes in the street. Why would any sane person dash out onto a busy street to risk their life to measure some holes in the ground? I must confess that I asked myself that question several times that day and other days while I helped develop our "unobtrusive" measures of road conditions. The answer to that question takes a somewhat long route but will be the focus of this presentation.
\end{abstract}

\section{Measuring the output of Police}

The story begins in 1970 when we first started a series of studies comparing the levels of service output for small and large police departments serving relatively similar neighborhoods within metropolitan areas. Our substantive interest in police resulted from the repeated assertions that-small scale police agencies were less effective than large-scale 2 agencies.

In our attempt to examine these assertions empirically, we first used a series of measures derived from citizen surveys. The first type of measure was that of citizen experiences with crime and with police. These included:

- Whether anyone in the household had been the victim of criminal activity.

- If a victimization incident had occurred, whether the police were notified. 
- If notified, how fast the police had responded.

- If the police responded, what level of activity was undertaken.

- Whether anyone in the household had called upon the police for assistance to deal with a noncriminal, but emergency problem.

- If assistance was requested, how fast did the police respond.

- If assistance was provided, what level of activity was undertaken.

- Whether respondents had been stopped by police serving their neighborhood.

- Whether respondents knew anyone who had been mistreated by police serving their neighborhood.

Secondly, we utilized a series of indicators of citizen evaluations

of service levels. These included:

- How fast respondents thought police serving their neighborhood responded to calls for service.

- Whether respondents thought crime in the neighborhood was rising, about the same or decreasing.

- Whether respondents thought that police-community relations were outstanding, good, adequate, inadequate or very poor.

- Whether respondents thought that the job performed by police serving their neighborhood was outstanding, good, adequate, inadequate, or very poor.

- Whether respondents thought that police services were equally available to all in their community.

In later studies we added to this list of measures (derived from random samples of citizens living in matched neighborhoods being served by varying sized departments) by including measures derived from interviews with police and from other agency records. ${ }^{3}$ Some of these were:

- The evaluation given by officers to the performance of their own department.

- The ratings given by a pool of police officers serving a metropolitan area to the departments in the area. 
o The proportion of reported crimes cleared by arrest.

- The proportion of warrants issued by the prosecutor to warrants applied for.

\section{Findings}

Using such multiple measures of police output, in a series of studies conducted in Indianapolis, chicago, st. Louis, and then replicated in Grand Rapids and Nashville-Davidson County, we found a consistent pattern across indicators of output." Larger police agencies serving carefully matched neighborhoods were not more effective. Small departments performed either at equal or higher levels across the range of a l 1 indicators used. Having used a series of different indicators, we can make much more confident statements about the relative effectiveness of large and small police departments than if we had used a single measure of output.

\section{Primary Reliance on One Mode of Data Collection}

However, many of our individual measures of output were derived from one mode of data collection -- that of individual interviews with respondents selected by a random process. Many scholars and public officials are uneasy about any reliance upon data collected from a survey of citizens about public agency performance. Citizens are thought by some to be uninformed and unable to give reliable perceptions and/or evaluations of service levels. Whether one agrees with this view or not (we obviously do not), reliance upon any single mode of measurement can lead to errors or biases in measuring performance or productivity.

This challenge to a particular mode of data collection about the output of public agencies led us to design a study in which measures of output were obtained from multiple modes of data collection. ${ }^{5}$ We wanted 


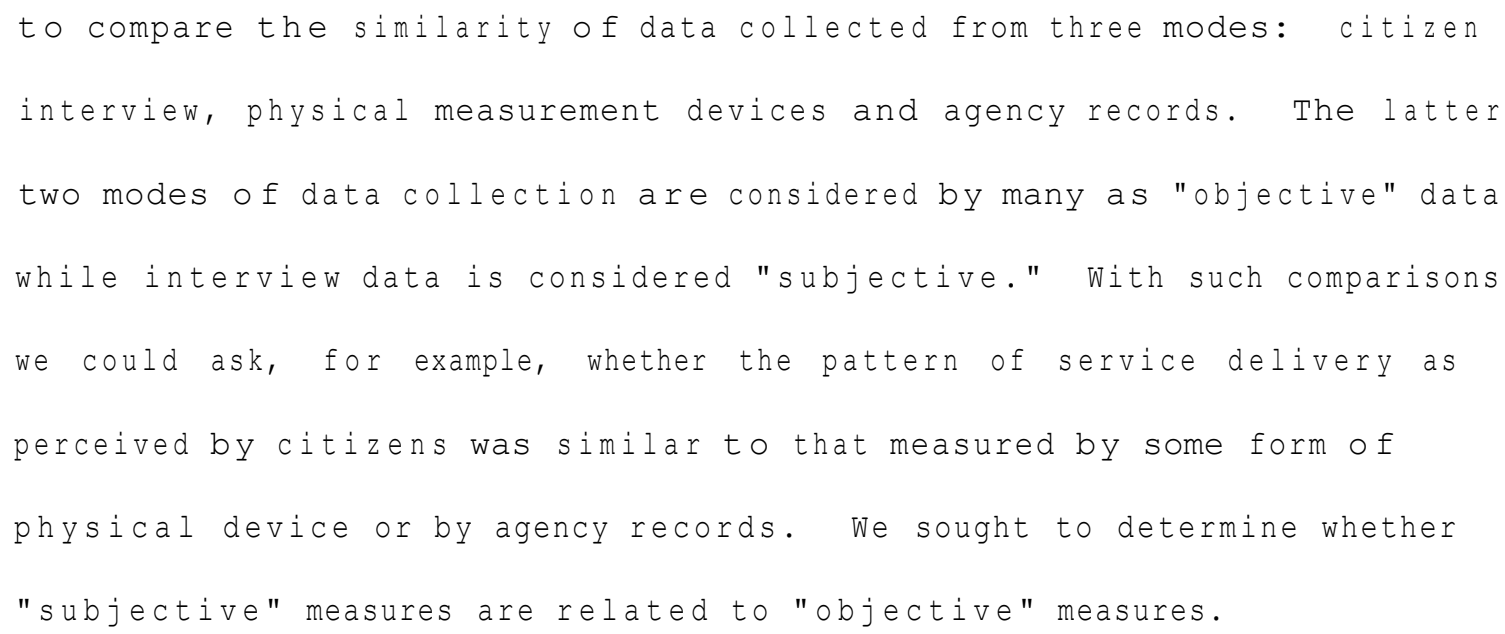

Measuring Road Condition and Street Lighting

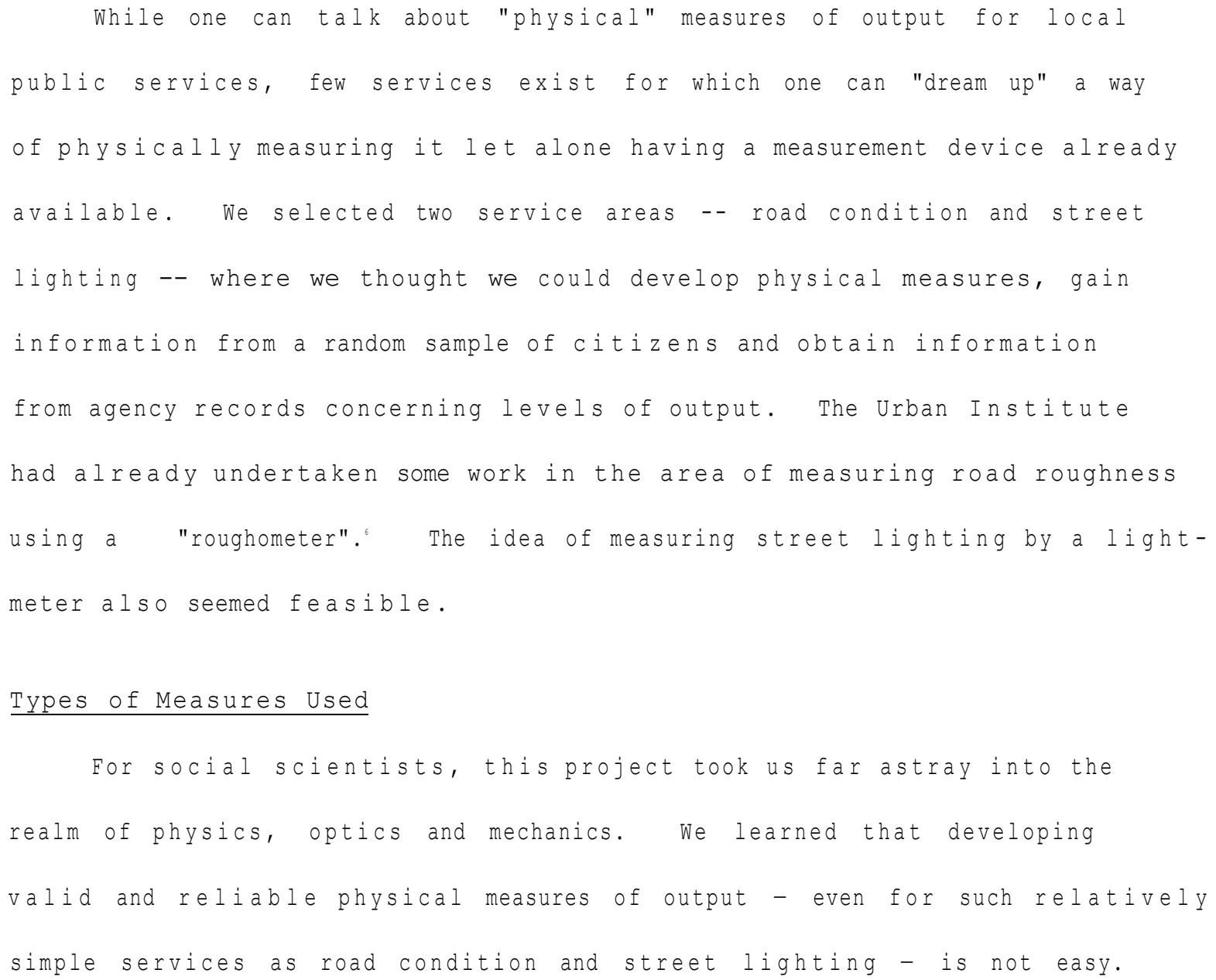




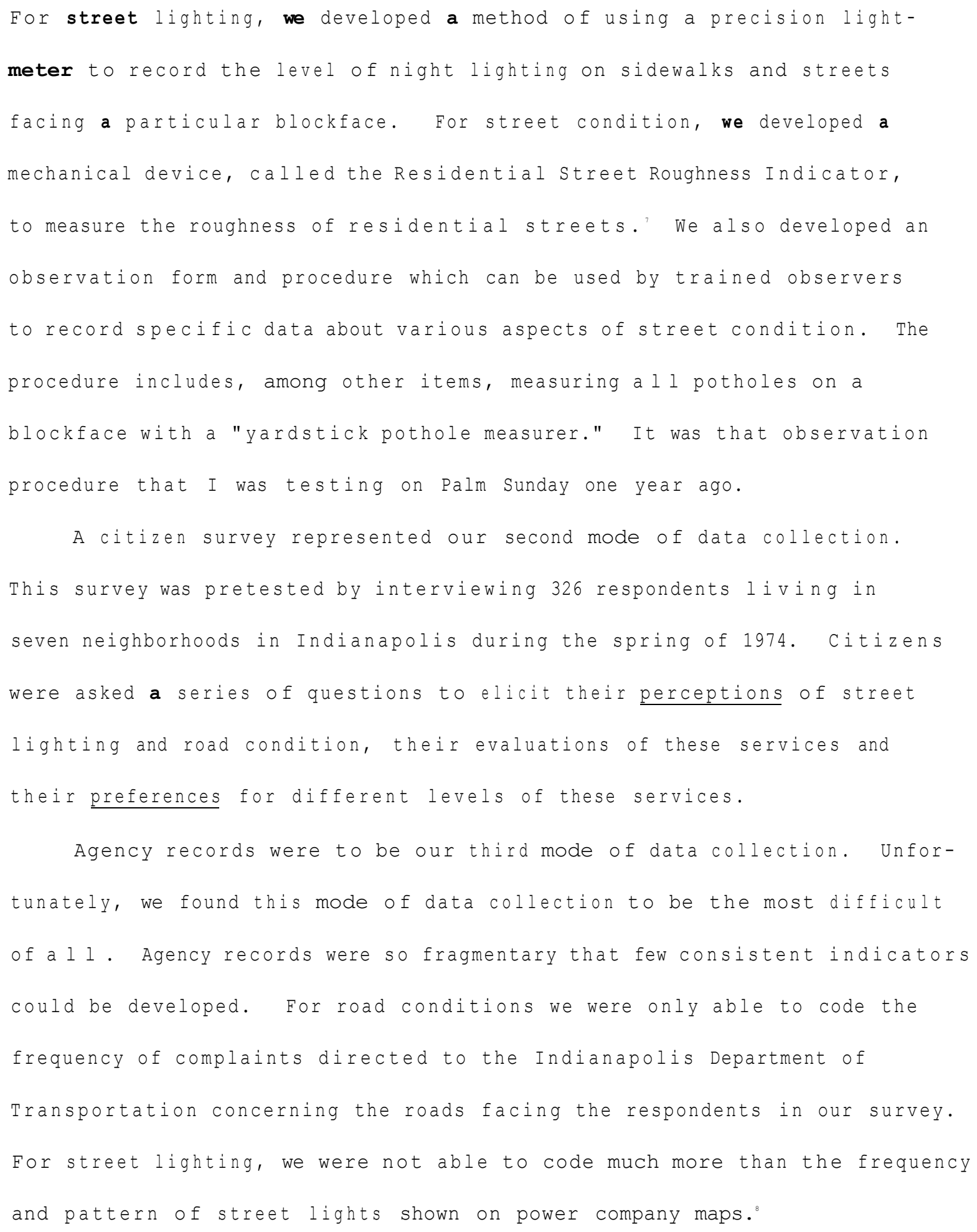




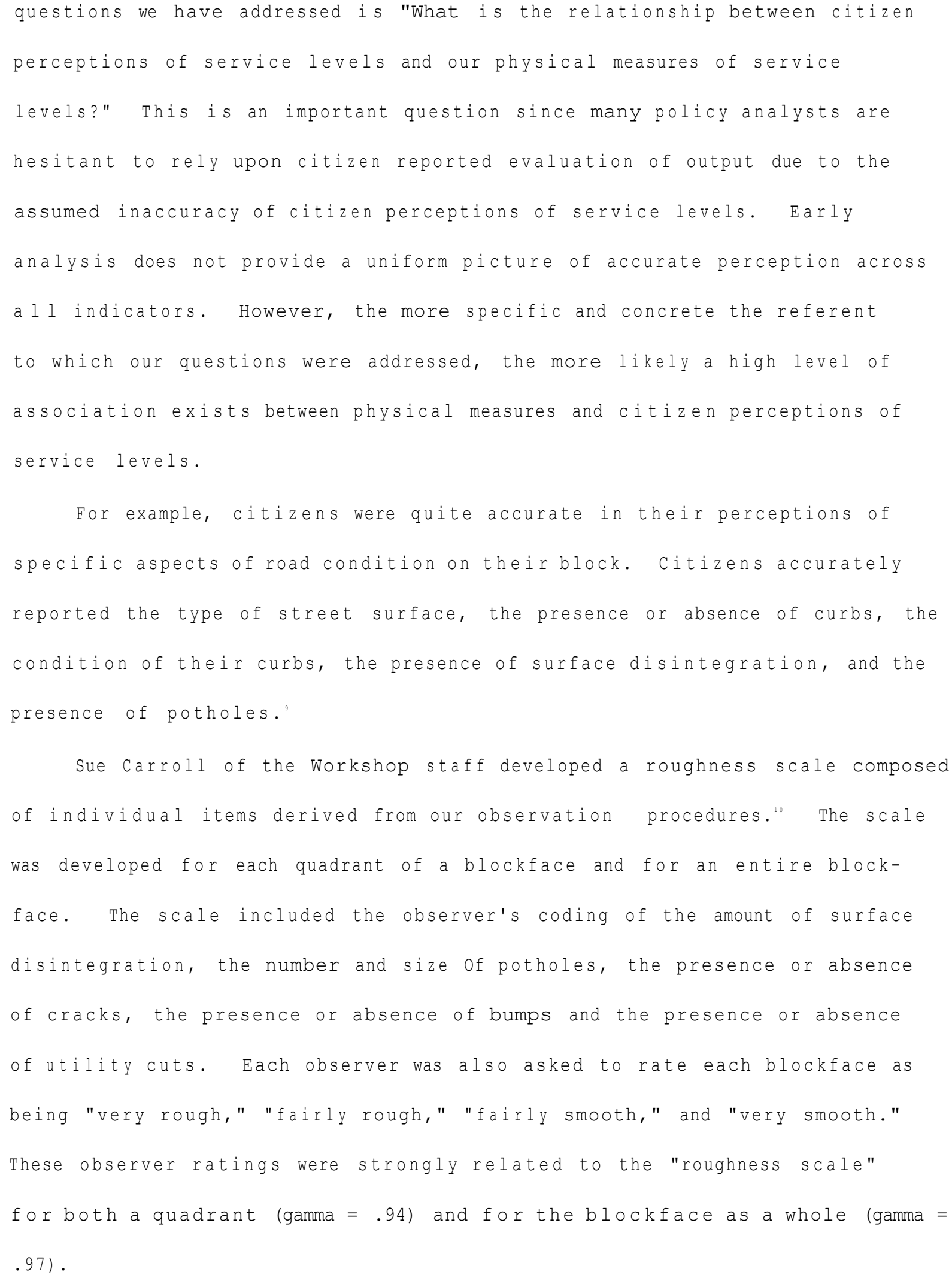


When respondents' perceptions of the roughness of the street on their block were then associated with the quadrant and blockface roughness scale, the measure of association between them is fairly strong (gamma = .76 for both scales). Some variation occured across various control variables. Those persons with more than a high school diploma, those over 45, those who have lived on a block more than five years, and those living on medium to short blocks tended to be more "accurate" in their perceptions of road roughness. Initial data analysis with scores produced by the Residential street Roughness Indicator device are consistent with these findings. A high association exists among all these individual modes of data collection concerning the level of road roughness. The perceptions of citizens, the output from a mechanical device for measuring road roughness and the coded observations of trained field-workers are strongly associated.

Although the levels of association are not, in general, as high as in the case of street condition, statisticallysignificantcorrelations between citizen perceived streetlight brightness levels on theirblockface and data from a precision photoelectric meter were found. ${ }^{11}$ Further, a distinct pattern emerged between the strength of association and the distance on either side of a respondent's house over which light-meter readings were averaged. Correlations reach a maximum when meter readings are averaged over intervals relatively proximate to a respondent's home and decline as the meter readings are averaged over widening intervals. The lowest correlation is between citizen perceptions of streetlight brightness and light-meter readings averaged for an entire blockface. For some subsets of the sample, this correlation was not statistically significant. Citizens, thus, appear to show a pronounced tendency 


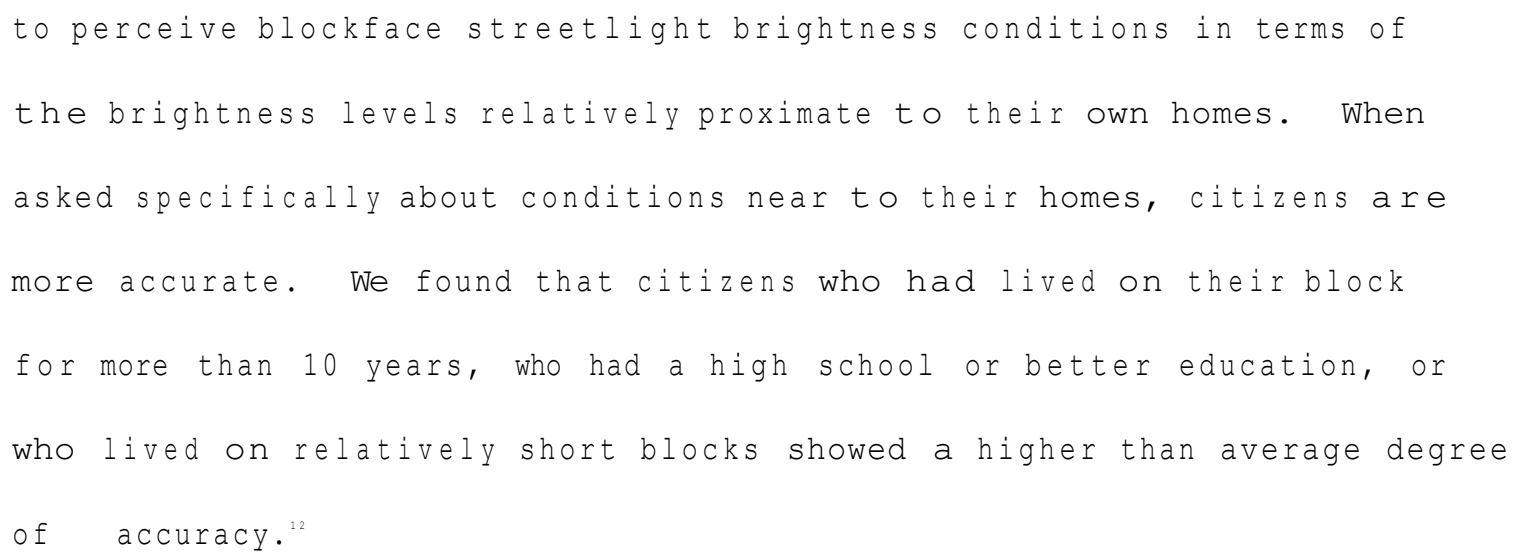

\section{Significance of Findings}

Ascertaining the Least Expensive, Valid Measure of output

The finding that measures derived from interviews with citizens

and measures derived from physical devices or field observation forms

are positively related for two service areas has considerable importance

for those interested in measuring the productivity of local public service

agencies. In the first place, given the close association between the

diverse modes of data collection regarding road conditions, public

officials or public interest groups concerned in ascertaining the relative productivity of agencies engaged in road repair activities can select the mode of data collection which is least expensive. The results obtained should correlate highly with results obtained from more expensive modes of data collection. Thus, we can increase the productivity of measuring productivity! Of the three modes of data collection compared -- the Residential street Roughness Indicator, the field observation form and the citizen survey - the field observation form is the least expensive mode of data collection.

The Workshop in Political Theory and Policy Analysis is currently preparing a "Portfolio of Professional Papers" on "Multiple Measures of 


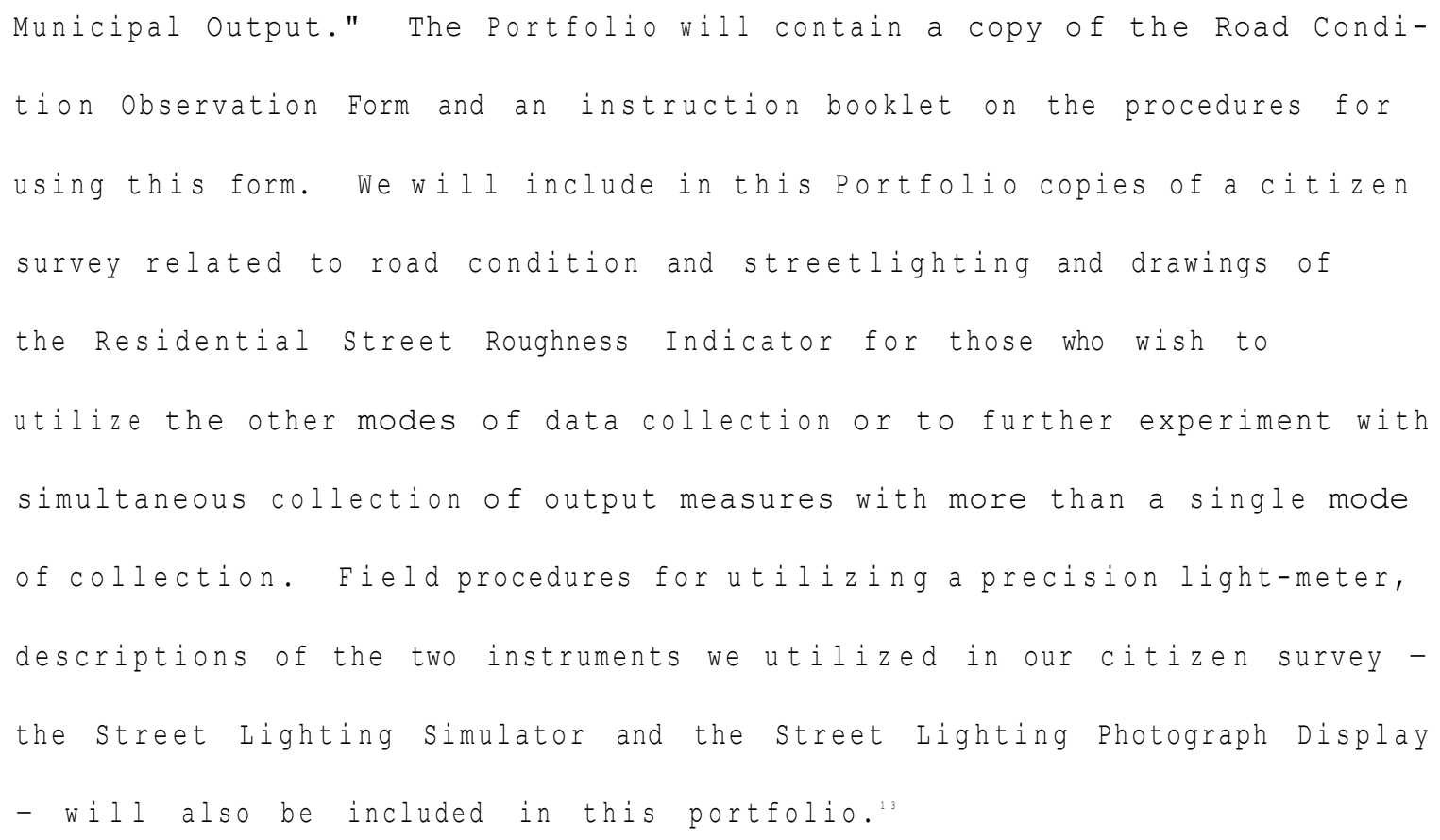




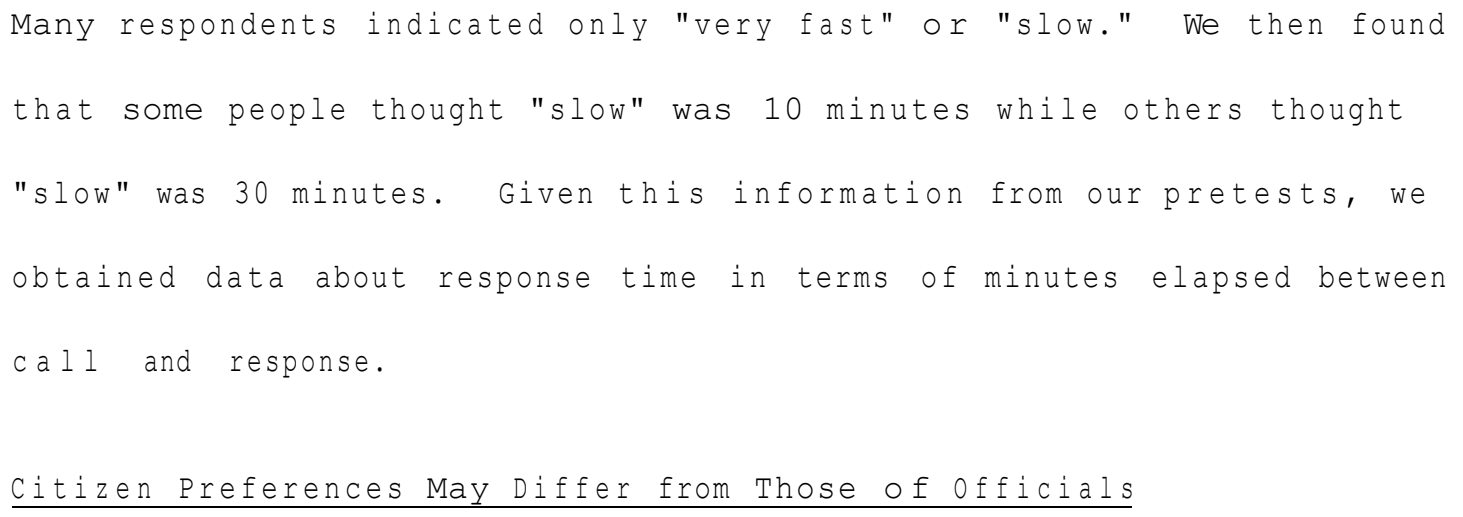




\section{Testing Ways to Improve Productivity}

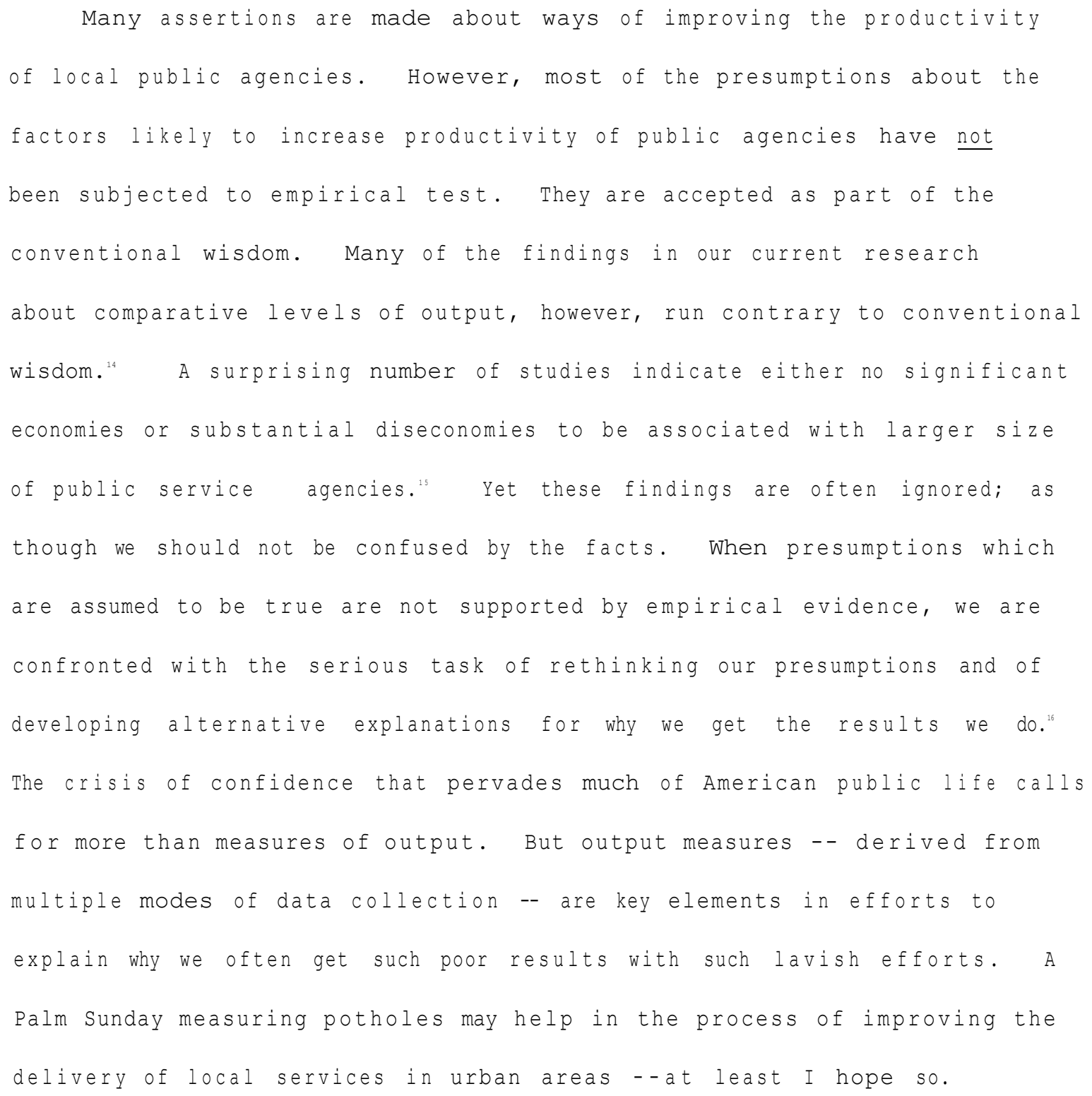




\section{FOOTNOTES}

See Elinor Ostrom, William H. Baugh, Richard Guarasci, Roger B. Parks, and Gordon P. Whitaker, Communty Organization and the Provision of Police Services, Sage Professional Papers in Administrative and Policy Studies 03-001 (Beverly Hills, California: Sage Publications, 1973); Elinor Ostrom, Roger B. Parks and Gordon P. Whitaker, "Do We Really Want to Consolidate Urban Police Forces? A Reappraisal of Some Old Assertions," Public Administration Review 33 (September/october 1973), 423-433; Elinor Ostrom and Gordon P. Whitaker, "Community Control and Governmental Responsiveness: The Case of Police in Black Communities," in David Rogers and Willis Hawley, eds., Improving the Quality of Urban Management, Vol. 8, Urban Affairs Annual Reviews (Beverly Hills, California: Sage Publications, 1974), pp. 303-334; Bruce D. Rogers and C. McCurdy Lipsey, "Metropolitan Reform: Citizen Evaluations of Performances in Nashville-Davidson County, Tennessee," Publius 4 (Fall 1974), 19-34; and S.T. Ishak, "Consumers' Perception of Police Performance: Consolidation vs. Deconcentration; The Case of Grand Rapids, Michigan Metropolitan Area" (Ph.D. Dissertation, Indiana University, 1972); Elinor Ostrom, "Size and Performance in a Federal System" Publius 5 (forthcoming); Roger B. Parks, "Complementary Measures of Police Performance," in Kenneth M. Dolbeare, ed., Evaluative Research (Beverly Hills: Sage Publications, 1976).

\section{2}

National Advisory Commission on Criminal Justice Standards and Goals, Report on Police (Washington, D.C. : Government Printing Office, 1973).

* Scholars at the Urban Institute have also been concerned with the problems of developing measures of police productivity. See Harry P. Hatry, "Wrestling with Police Crime Control Productivity Measurement," in Joan L. Wifle and John F. Heaphy (eds) Readings on Productivity in Policing (Washington, D.C: The Police Foundation, 1975), pp. 86-128; Peter B. Bloch, Equality of Distribution of Police Services - A Case Study of Washington, D.C. (Washington, D.C: The Urban Institute, 1974).

See citations in footnote 1.

${ }^{5}$ For a more detailed description of this project see Vernon Greene, Elinor Ostrom, Roger Parks and Richard Rich, "The Measures Project - A Theoretical and Methodological Overview," (Bloomington, Indiana: Indiana University, Department of Political Science, Workshop in Political Theory and Policy Analysis, Research Report Number 1) and Elinor Ostrom, "The Need for Multiple Indicators in Measuring the Output of Public Agencies," Policy Studies Journal 2 (Winter 1973), pp. 87-91.

6

See Andrew J. Boots, Grace Dawson, William Silverman, Harry P. Hatry, Inequality in Local Government Services: A Case Study of Neighborhood Roads (Washington, D.C: The Urban Institute, nodate). 
${ }^{7}$ See Richard Rich, "The Development of a Technique for the Physical Measurement of Residential Street Lighting," (Bloomington, Indiana: Indiana University, Department of Political Science, Workshop in Political Theory and Policy Analysis, Research Report Number 5).

${ }^{8}$ The power company has available to it, computer programs which can calculate expected light intensity on a street given light type, spacing, etc. These programs are not used, however, in any attempt to evaluate output.

${ }^{9}$ See Sue Carroll, "An Analysis of the Relationship Between Citizen Perceptions and Inobtrusive Measures of Street Conditions," (Bloomington, Indiana: Indiana University, Department of Political Science, Workshop in Political Theory and Policy Analysis, Research Report Number 10).

10 Ibid.

${ }^{11}$ See Vernon Greene, "An Analysis of the Relationship Retween Citizen Perceptions and Physical Measures of Street Lighting," (Bloomington, Indiana: Indiana University, Department of Political Science, Workshop in Political Theory and Policy Analysis, Research Report Number 7).

12 Ibid.

13 These portfolios will be available by writing to: Publication's Secretary, Workshop in Political Theory and Policy Analysis, Indiana University, Morgan Hall 121, Bloomington, Indiana 47401.

${ }^{14}$ See citations in footnote 5 and 81 inor Ostrom and Roger B. Parks "Suburban Police Departments: Too Many and Too Small?" in Louis H. Masotti and Jeffrey K. Hadden, eds., The Urbanization of the Suburbs (Beverly

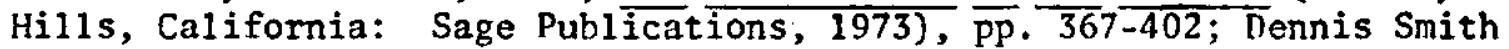
and Elinor Ostrom, "The Effects of Training and Education on Police Attitudes and Performance," in Herbert Jacol, ed. The Potential for Reform of Criminal Justice (Beverly Hills: Sage Fuilitations, 1974), pp. 45-32; James C. McDavid, "Interjurisdictional Cooperation Among Police Departments iil the St. Louis Metropolitan Area," Publius 4 (Fa11 1974), pp. 35-58; Elinor Ostrom and Dennis Smith, "Are the Lilliputs in Metropolitan Policing Failures?", paper presented at the American Society for Public Administration meetings in Chicago, April 2, 1975.

15 For a review see Rohert L. Bish and Vincent Ostrom, Inderstanding Urban Government: Metropolitan Reform Reconsidered. (Washington, D.C.: American Enterprise Institute, 1973).

${ }^{16}$ See Vincent Ostrom, The Intellectual Crisis in American Public Administration (University, Alabama: University of Alabama Press, 1973). 